\title{
Membangun Generasi Cerdas Berhukum
}

\section{Building a Smart Generation of Punishment}

\author{
Arief Wahyudi* \\ Jurusan Pendidikan Pancasila dan Kewarganegaraan (PPKn) \\ Fakultas Ilmu Sosial Universitas Negeri Medan, Indonesia
}

\begin{abstract}
Abstrak
Hukum memiliki relasi yang kuat dengan manusia dan mempengaruhi kehidupan manusia setiap saat. Pada konteks ini hukum dihadirkan bagi manusia untuk menjembati berbagai kepentingan dalam relasi sosial antara manusia, sehingga campur tangan manusia menjadi faktor dominan untuk menentukan tegak atau runtuhnya hukum. Di sinilah diperlukan kecerdasan berhukum itu yakni, bagaimana suatu bangsa memaknai hukumnya sendiri dan menjadikan dirinya sebagai bagian integral dari sistem hukum yang dianutnya dan pada konteks ini pula generasi yang cerdas hukum perlu dibangun. Peran membangun generasi cerdas berhukum ini dapat dilakukan oleh mahasiswa sebagai elemen kepemudaan yang memiliki nilai-nilai strategis dengan didukung oleh elemen-elemen pada proses pembelajaran dan perannya pada dinamika sosial masyarakat. Tantangan bagi mahasiswa adalah mencerdaskan keberhukumannya sendiri sebelum mencerdaskan masyarakat secara umum. Kata Kunci: Cerdas Berhukum, Generasi Muda, Mahasiswa.
\end{abstract}

\begin{abstract}
Law has a strong relationship with humans and affects human life at all times. In this context the law is presented for human beings to fulfill the various interests in the social relations between humans, so that human intervention becomes the dominant factor in determining the erect or the collapse of the law. This is where the necessary intelligence of punishment is, how a nation interpret its own law and make itself an integral part of the legal system it embraces and in this context also a smart generation of law needs to be built. The role of building the intelligent generation of punishment can be done by students as a youth element that has strategic values supported by elements in the learning process and its role in social dynamics of society. The challenge for students is to educate their own penalties before educating the public in general.
\end{abstract}

Keywords: Punitive Smart, Young Generation, Student.

How to Cite: Wahyudi, A., (2017). Membangun Generasi Cerdas Berhukum. JPPUMA: Jurnal Ilmu Pemerintahan dan Sosial Politik UMA, 5 (2): 116-125

*Corresponding author:

p-ISSN: 25491660

E-mail: rf.wahyudi@gmail.com

e-ISSN: $2550-1305$ 


\section{PENDAHULUAN}

Tulisan ini menggunakan terminologi "Cerdas Berhukum" sebagai judul, bukan "Cerdas Hukum". Penggunaan terminologi "Cerdas Berhukum" ini untuk menekankan internalisasi hukum dalam konteks kehidupan dan melihat hukum secara lebih luas tidak hanya pada batas-batas pengetahuan tentang hukum, tetapi juga bagaimana hukum itu diketahui dan diimplementasikan pada pratek yang nyata serta kebijaksanaan-kebijaksanaan yang mestinya muncul pada praktek itu.

Sebagai gambaran untuk melihat konsep cerdas berhukum, dapat dilihat sebagaimana dituliskan oleh Stajipto Rahardjo (Prof Tjip) pada bagian kata pengantar untuk buku beliau berjudul "Biarkan Hukum Mengalir Catatan Kritis Tentang Pergulatan Manusia dan Hukum" berikut ini:

"Oleh karena itu, buku ini banyak membicarakan tentang "cara berhukum", "cara manusia berhukum", cara suatu bangsa berhukum", sesuatu yang belum lazim digunakan dalam tulisan menggenai hukum. Buku ini tidak pernah berhenti "mencurigai" berkelebatnya manusia sebagai dinamisator hukum, baik dalam hal menciptakan dan menjalankan (making law), maupun mematahkan dan merobohkannya (breaking the law). (Rahardjo, 2007)

Gambaran yang disampaikan Prof. Tjip tersebut menunjukkan bahwa cerdas berhukum tidak hanya pada batas-batas pengetahuan hukum dan kebersediaan untuk menaatinya, tetapi juga meliputi kesadaran bahwa kita adalah bagian dari implementasi hukum itu sendiri yang dengan kesadaran itu akan menentukan apakah hukumnya akan mencapai tujuannya atau tidak. Bagaimana manusia akan memainkan perannya sebagai dinamisator hukum lah yang dituju oleh terminologi "cerdas berhukum" yang digunakan pada tulisan ini.

\section{PEMBAHASAN}

\section{Ilustrasi Pengaruh Hukum Dalam Masyarakat}

Hukum lahir, tumbuh dan berkembang dalam kehidupan bersama sebagai masyarakat. Dinamika pada kehidupan bersama itulah yang diatur oleh hukum. Semakin kompleks kehidupan bersama itu, semakin kompleks pula hukumnya dikarenakan semakin kompleks pula hubungan-hubungan hukum yang muncul dalam kehidupan bersama itu.

Relasi hukum dalam kehidupan manusia bermasyarakat ini oleh Van Apeldorn dijelaskan sebagai berikut:

"Manusia setiap saat dikuasai oleh hukum. Hukum mencampuri urusan manusia sebelum ia lahir dan masih mencampurinya sesudah meninggal. Hukum melindungi benih di kandungan ibu dan masih menjaga jenazah orang yang telah mati. Ia memberikan seseorang langsung setelah ia dilahirkan, hak-hak terhadap ibu bapak dan meletakkan kewajiban atas ibu bapak terhadap anak-anaknya. Ikatan hukum yang jumlahnya tidak terhingga, menghubungkan manusia satu sama lain dengan dunia jasmani yang mengelilinginya. Pergaulan hidup manusia terjadi daripada hubungan yang jumlahnya tidak terhingga antara manusia dengan manusia, hubungan yang langsung dari asalusul, pertalian darah, perkawinan, tempat tinggal, kebangsaan, perdagangan, pemberian jasa yang beraneka warna (sewa-menyewa, pengangkutan, penyimpanan (bewaargeving), pinjaman uang, asuransi dan sebagainya). Semua hubungan tersebut diatur oleh hukum, semuanya adalah hubungan hukum (rechtbetrekkingen). (Apeldorn, 2005: 6)

Pada keadaan yang lebih realitis, seorang mahasiswa dapat digambarkan sebagai dikuasai oleh hukum mulai sejak bangun tidur sampai bangun tidur lagi esok harinya. Di dalam rumahnya 
mahasiswa tersebut telah dikenai oleh berenaka ragam hukum dalam arti peraturan perundang-undangan, misalnya peraturan tentang kewarganegaraan, tentang kekerasan dalam rumah tangga, tentang perlindungan anak, dan sebagainya. Dalam perjalanannya menuju kampus, mahasiswa tersebut dikenai oleh peraturan tentang lalu lintas, tentang ketertiban umum dan sebagainya. Ketika mahasiswa itu sedang bertransaksi di kantin, dia juga dikenai oleh peraturan tentang jual beli, perjanjian dan demikian juga kantin tersebut, juga dikenai oleh peraturan tentang perlindungan konsumen, pajak, perizinan usaha dan sebagainya. Saat menjalankan proses pembelajaran di kampus, dia juga dikenai oleh undang-undang tentang sistem pendidikan yang ada. (Friedmen, 2001)

Ilustrasi ini menunjukan bahwa hukum adalah bagian yang integral dalam kehidupan seseorang di dalam masyarakat. Tidak adanya interaksi antara manusia dengan manusia dengan segala kepentingannya, tidak memunculkan hubungan-hubungan hukum sebagaimana diilustrasikan di atas. Manusia "sendirian" tidak memerlukan hukum untuk dirinya sendiri, melainkan hukum itu muncul pada proses interaksinya.

Yang dimaksud dengan manusia "sendirian" di sini adalah, manusia yang tidak memiliki interaksi dengan manusia lainnya. Cukup banyak ilustrasi tentang manusia "sendirian" ini yang ditulis oleh berbagai penulis sejak zaman dulu. Misalnya kisah Hay Bin Yaqzan yang ditulis oleh Ibnu Thufail. Selain itu juga ada kisah Tarzan, Kisah Mowgli The Jungle Book dan kisah Robinson Crusoe. Kisahkisah itu menggambarkan manusia "sendirian" dalam kehidupannya dan hidup bersama hewan-hewan karena tidak adanya manusia lainnya dan tidak adanya interaksi dengan manusia lain. Pada keadaan ini, tokoh-tokoh tersebut tidak memerlukan berbagai hukum seperti hukum pidana, perdata, tata negara maupun hukum internasional. Kisah-kisah ini dapat di cari menggunakan mesin pencari online dengan mengetikan namanama tersebut sebagai kata kunci.

Sebagai contoh, mahasiswa yang kost dengan kamar yang hanya untuk dirinya sendiri, tidak memerlukan hukum bagi dirinya sendiri pada saat dia berada di dalam kamar. Dia bebas melakukan kehendaknya di dalam kamar itu. Hukum baru muncul ketika pada pelaksanaan kehendak itu bersinggungan dengan kepentingan orang lain seperti kehendak memutar musik dengan volume yang keras dapat mengganggu kepentingan mahasiswa lain yang sedang belajar di kamar sebelahnya. Pada konteks inilah diperlukan jembatan kepentingan yang di atur oleh hukum yang pengaturannya mesti memperhatikan seluruh kepentingan yang ada dan kemungkinan pengaturan itu akan berlaku efektif untuk masa yang akan datang.

\section{Fenomena Keberhukuman}

Meski hukum secara teoritik ditujukan untuk menghadirkan keadilan, menciptakan ketertiban, mendatangkan kemanfaatan, serta memberikan pengayoman terhadap berbagai pemenuhan kepentingan, namun pada prakteknya tidak selalu se-ideal itu. Praktek berhukum tidak jarang memunculkan masalah-masalah yang justru menyimpang dari nilai-nilai ideal yang hendak ditujunya.

Banyak contoh yang bisa dikemukakan di sini khusus untuk fenomena keberhukuman di Indonesia saja. Beberapa contoh vonis hakim yang fenomenal diantaranya vonis terhadap pembunuh Muhammad Asrori di Jombang Jawa Timur vonis terhadap nenek Minah di Purwokerto, vonis terhadap Aguswandi Tandjung di Jakarta dan Kasus Prita Mulyasari melawan Rumah Sakit Omni Internasional di Tanggerang, Banten. Kronologis dan perkembangan masingmasing kasus yang dijadikan contoh ini dapat diikuti melalui pemberitaan website media massa menggunakan fasilitas mesin pencari online yang banyak tersedia di internet dengan cara mengetikan nama 
kasus tersebut sebagai keyword pada search engine.

David Eko Prasetyo, Imam Hambali (Kemat) dijatuhi vonis oleh Pengadilan Negeri Jombang, masing-masing 12 tahun penjara melalui Putusan Nomor 48PID.B/2008/PN JMB, karena dinyatakan sebagai pembunuh Muhammad Asrori. Namun, belakangan diketahui ternyata david dan Kemat bukanlah pembunuh yang sebenarnya melainkan pembunuhan dilakukan oleh Very Idham Heryansyah yang dikenal sebagai Ryan Sang Penjagal sebagai pelaku pembunuhan dan tes DNA yang menunjukkan bahwa mayat yang dinyatakan sebagai mayat Asrori ternyata bukanlah Asrori, melainkan Mayat Fauzin Suyanto. Nenek Minah divonis 1 bulan 15 hari dengan masa percobaan 3 bulan oleh Pengadilan Negeri Purwokerto karena mencuri 3 biji Kakao milik PT. Rumpu Sari Antan senilai Rp. 2.100,(http://www.dudungnet.com. "Kasus Minah..." Diakses tanggal 8 Juli 2011). Aguswandi Tandjung divonis 6 bulan kurungan dengan masa percobaan 1 tahun oleh Pengadilan Negeri Jakarta Pusat karena men-charge Handphone di apartemen yang dikelola oleh Roxy Mas. (http://www.primaironline.com/berita/hukum/ aguswandi-tandjung-charger-hp-divonis-6bulan-bui Diakses tanggal 8 Juli 2011)

Prita Mulyasari digugat secara perdata dan dituntut pidana oleh Rumah Sakit Omni Internasional untuk kasus pencemaran nama baik berdasarkan UU No.11 Tahun 2008 Tentang Informasi dan Transaksi Elektronik karena mengeluhkan layanan buruk yang diterimanya pada saat dirawat kepada beberapa orang temannya melalui surat elektronik (email). (http://www.elsam.or.id/images/uploads/amic us_curiae_prita.pdf. Diakses tanggal 8 Juli 2011). Prita dikalahkan oleh Pengadilan Negeri Tangerang pada perkara perdata dan diputus untuk membayarkan ganti rugi materil sebesar Rp. 161 juta dan ganti rugi immateril sebesar Rp. 100 juta, sedangkan untuk kasus pidana, Prita ditahan oleh kejaksaan namun tuntutan Jaksa Penuntut Umum dinyatakan batal demi hukum oleh Pengadilan Negeri Tanggerang.

(http://www.elsam.or.id/images/uploads/amic us_curiae_prita.pdf. Diakses tanggal 8 Juli 2011)

Vonis-vonis yang dijatuhkan pengadilan ini memunculkan polemik di kalangan masyarakat dan oleh sebagian kalangan dinyatakan sebagai hilangnya keadilan hukum dan kuatnya hukum jika berhadapan dengan masyarakat yang lemah dalam hal status sosial dan ekonomi. Untuk kasus Prita, muncul gerakan solidaritas "koin untuk prita" dapat diartikan sebagai bentuk protes masyarakat terhadap putusan hakim yang menyatakan bersalah bagi orang yang mengeluhkan buruknya layanan publik yang diterimanya. Pada konteks ini, hukum yang dihasilkan melalui putusan hakim itu di tolak oleh masyarakatnya meski secara normatif proses hukumnya tetap berjalan.

Fenomena ini kontras sekali dengan berbagai peristiwa hukum lainnya yang terjadi yang melibatkan kekuasaan dan kewenangan di dalamnya baik di lembaga peradilan maupun pada konteks kehidupan sehari-hari. Pada konteks pengadilan misalnya dapat dilihat pada putusan Hakim Praperadilan yang memenangkan Setya Novanto melawan KPK di Pengadilan Negeri Jakarta Selatan yang kemudian memunculkan polemik di masyarakat terkait apakah putusan itu tepat atau tidak. Putusan hakim Praperadilan untuk kasus ini dapat diikuti dengan melalui pemberitaan terutama pemberitaan online dengan menggunakan mesin pencari online dengan keyword Putusan Praperadilan Setya Novanto.

Pada kehidupan sehari-hari, muncul juga beberapa kasus kongkalikong oknum Polisi Lalu Lintas dengan masyarakat (termasuk juga kalangan mahasiswa) untuk sama-sama melanggar dan/atau menggabaikan mekanisme hukum yang diatur dalam Undang-Undang Nomor 22 Tahun 2009 Tentang Lalu Lintas dan Angkutan Jalan. 
Pada konteks ini, tepat sekali apa yang disampaikan oleh Prof Tjip berikut ini:

"Cara kita berhukum dapat terjebak ke dalam kotak legalisme-formal, yaitu memberikan pengutamaan kepada pembacaan dari apa yang tertulis. Cara yang demikian memang tak dapat sama sekali disalahkan, oleh karena memang negara kita adalah sebuah negara hukum dan dalam negara hukum modern tentunya kita harus berangkat dari teks-teks tertulis. Yang dimaksud dengan terjebak di sini adalah, manakala kita membiarkan diri kita secara total diikat oleh undang-undang dan prosedur"

..., bahwa hukum itu tidak ada untuk dirinya sendiri, melainkan untuk manusia dan masyarakat. Berangkat dari situ maka menjalankan hukum tidak dapat dilakukan secara matematis atau dengan cara yang saya sebut sebagai "mengeja pasalpasal undang-undang”. ... dalam hukum itu tidak hanya ada satu logika, yaitu logika hukum, melainkan juga logika filsosofis, dan sosial. Ketiga-tiganya akan selalu berada dalam persaingan satu sama lain." (Rahardjo, 2007: 86-87)

\section{Cerdas Berhukum}

Fenomena-fenomena yang digambarkan di atas menunjukan bahwa campur tangan manusia merupakan faktor dominan tegak atau runtuhnya hukum. Cara bagaimana manusia dan komunitas manusia itu berhukum menentukan hukum itu akan memberikan kebaikan atau malah mendatangkan keburukan. Bahkan, pada pengertian hukum sebagai peraturan tertulis yang dibuat oleh lembaga yang berwenang dengan seperangkat sanksi untuk menjamin hukum ditaati, belum tentu hukum akan benar-benar ditaati oleh masyarakat yang dituju oleh hukum itu. Di sinilah diperlukan kecerdasan berhukum itu yakni, bagaimana suatu bangsa memaknai hukumnya sendiri dan menjadikan dirinya sebagai bagian integral dari sistem hukum yang dianutnya.

Prof Tjip menuliskan ilustrasi perbedaan bangsa Amerika dan bangsa Jepang dalam berhukum sebagai berikut:

“... Bangsa Amerika berhukum dengan menggunakan akal pikiran, sebagaimana umumnya negaranegara di Barat. Jepang sebaliknya, adalah bangsa dengan cara berhukum yang didasarkan pada hati (kokoro). Perbedaan tersebut dicontohkan melalui suatu kejadian yang melibatkan seorang Amerika dan seorang Jepang. Mereka berdua berdiri di pinggir jalan, menunggu kesempatan untuk menyeberang jalan, karena lampu lalu-lintas masih merah. Pada saat lalu lintas mobil sudah sepi, orang Amerika mengajak teman Jepangnya untuk menyeberang. Jawab orang Jepang, "Kalau lampu lalu-lintas masih merah lalu saya menyeberang, muka saya ini mau saya taruh di mana?".

...

... Saya membayangkan bagaimana andaikata di hukum Amerika Serikat dan Jepang itu dicabut. Kemungkinan besar Amerika akan kembali menjadi "the wild wild West", sedang Jepang tetap tertib, oleh karena cara berhukum bangsa ini tidak didasarkan pada akal pikiran, tetapi hatinya." (Rahardjo, 2007:18-19)

Pada bagian yang lain dalam bukunya itu, Prof Tjip mencontohkan perbedaan antara orang Amerika dengan orang Jepang menyelesaikan permasalahan hukum yang sama, yakni penyelesaiaan untuk persoalan kecelakaan pesawat terbang yang menewaskan ratusan orang. Pada saat terjadi kecelakaan pesawat di Amerika, para lawyer dari pihak maskapai dan korban, saling 'bertarung' di pengadilan untuk mewakili kepentingan masing-masing. Lawyer korban berusaha untuk mendapatkan ganti kerugian 
semaksimal mungkin dan lawyer perusahaan bekerja keras untuk membatasi penggantian kerugian itu untuk kemudian diputuskan oleh pengadilan. Meskipun secara normatif sistem hukum jepang juga menganut model hukum Amerika itu, namun mekanisme yang dilakukan di Jepang berbeda dengan yang dilakukan di Amerika. Pada peristiwa kecelakaan pesawat di Jepang, pemimpin tertinggi perusahaan menggumpulkan keluarga para korban, membungkuk dalam-dalam dan lama sebagai permintaan maaf. Para staf perusahaan kemudian membantu dan mendampingi keluarga korban mengenali jenazah sampai pada proses pemakaman serta penyelenggaraan acara penghormatan arwah dengan dana yang ditanggung oleh perusahaan. Perusahaan itu juga menyediakan dana beasiswa untuk membiayai pendidikan anak-anak korban dan setelah seluruh prosesnya selesai, pimpinan tertinggi perusahaan itu mengundurkan diri. Masalahnya dapat diselesaikan dengan baik tanpa harus 'bertarung' di pengadilan. (Rahardjo, 2007: 63-76)

Ilustrasi Prof Tjip tersebut bukanlah tentang perbandingan sistem hukum Amerika lebih baik dari sistem hukum Jepang, bukan juga untuk mengatakan bahwa cara berhukum orang Jepang lebih baik dari cara berhukum orang Amerika atau sebaliknya melainkan seperti itulah bangsa-bangsa itu memaknai hukumnya dan berhukum menurut cara yang dimaknainya itu. Bagi orang Amerika, seperti itulah mereka memaknai hukumnya, yakni pada konteks formal dan memunculkan keterikatan normatif terhadap hukum itu yang kemudian menjadi motor bagi ketertiban hukum mereka. Sedangkan bagi orang Jepang, hukum itu melekat secara substantif sebagai bagian dari harga diri sehingga bukan mekanisme formal hukum yang utama, tapi nilai substantif dari hukum yang mereka anut.

Lebih lanjut Prof. Tjip menguraikan bahwa tidak ada cara berhukum yang sama secara total di dunia ini dimana masing-masing bangsa memilih dan menjalankan cara-cara berhukum menurut modal sosial yang mereka miliki. Oleh karenanya cara berhukum itu tidak dapat dipaksakan antara satu bangsa kepada bangsa lainnya. Pemaksaan itu hanya akan membuat bangsa-bangsa yang dipaksa menjadi tidak bahagia. (Rahardjo, 2007: 77)

Bagaimana dengan bangsa Indonesia, apakah juga memiliki cara berhukum sendiri? Secara konseptual, sebagaimana dituliskan Prof Tjip, tentu saja Indonesia juga berhak untuk berhukum menurut cara yang dipandangnya cocok. (Rahardjo, 2007: 77) Tapi, dengan segala fenomena berhukum yang ada, apakah Indonesia sudah menemukan cara berhukum yang cocok? Sudahkah hukum dan cara berhukum kita mampu menyelesaikan berbagai masalah dengan tuntas?

\section{Generasi Cerdas Berhukum dan Peran Mahasiswa}

Pertanyaan retorik di atas, apakah kita sudah menemukan cara berhukum yang tepat penting untuk menjadi perhatian bersama. Apakah segala fenomena hukum yang ada sekarang adalah cara berhukum yang cocok untuk kita atau segala kegaduhan itu merupakan penyimpangan dari keadaan yang sebenarnya?

Berkaca dengan ideologi Pancasila yang dianut sebagai fondasi bernegara dan rumusan tujuan bernegara pada pembukaan UUD NKRI 1945, jelas bahwa seluruh fenomena yang memunculkan kegaduhan hukum sebagaimana yang disaksikan akhir-akhir ini bukanlah cara berhukum yang cocok dengan bangsa Indonesia. Konstruksi hukum dengan ideologi Pancasila menunjukan bahwa hukum di Indonesia tidak hanya berbasiskan kehendak akal maupun moralitas semata seperti yang dicontohkan pada bangsa Amerika dan Jepang di atas. Konstruksi hukum Indonesia pada tataran ideal memiliki akar yang kuat pada 
keyakinan akan Ketuhanan serta pencapaian elemen keadilan dan keberadaban berbasiskan nilai-nilai kemanusiaan dengan tetap menjaga persatuan serta nilai-nilai demokrasi yang dianut untuk mewujudkan kesejahteraan bagi seluruh rakyat Indonesia. Melalui konstruksi hukum yang seperti itu, semestinya istilah-istilah seperti "hukum ada untuk dilanggar", "hukum tajam ke bawah dan tumpul keatas", "penegakan hukum tebang pilih" atau istilah lainnya yang menunjukan "sisi gelap" hukum Indonesia tidak perlu ada. Pada point inilah perlu diperiksa apa yang salah dalam sistem hukum di Indonesia sehingga tidak terbangun cara berhukum yang dikehendaki.

Secara umum Friedman menyebutkan bahwa sistem hukum itu meliputi tiga unsur, yakni struktur hukum, susbtansi hukum dan kultur atau budaya hukum. Struktur hukum merupakan kerangka atau rangka hukum, bagian yang tetap bertahan atau bagian yang memberi semacam bentuk dan batasan terhadap keseluruhan, misalnya penataan terhadap lembaga-lembaga hukum seperti badan legislatif dan kepolisian. Substansi hukum adalah aturan, norma, pola prilaku nyata manusia yang berada dalam sistem hukum itu, sedangkan budaya hukum adalah sikap manusia terhadap hukum dan sistem hukum itu. (Friedmen, 2001: 6-10)

Ketiga unsur sistem hukum itu menentukan apakah law enforcement sebuah negara akan berjalan baik atau tidak. Jika struktur hukum (misalnya polisi) sudah mengerjakan tugasnya dengan baik sedangkan substansi hukumnya bermasalah, penegakan hukumnya tidak akan maksimal. Demikian pula jika substansi hukum dan struktur hukum sudah baik tapi budaya hukum masyarakatnya tidak baik, penegakan hukumnya akan terhambat oleh berbagai masalah yang disebabkan budaya hukum itu.

Mengacu kepada konsepsi keberhukuman dengan manusia sebagai dinamisatornya, ketiga unsur tersebut sangat ditentukan oleh bagaimana cara berhukum yang ada. Manusia lah yang menentukan unsur-unsur hukum itu bersinergi sebagaimana mestinyan terlepas dari sistem hukum seperti apa yang dianut. Oleh karenanya kecerdasan berhukum itu dapat dimaknai dengan kecerdasan untuk mensinergikan ke unsur sistem hukum itu mencapai maksud diadakannya hukum. Struktur hukum akan berjalan baik jika lembaga-lembaga hukum ditata dengan baik dan orangorang di lembaga hukum itu melaksanakan tugas dan kewenangannya dengan baik pula. Substansi hukum akan baik, jika orang-orang di lembaga legislatif mampu menghasilkan peraturan perundangan-undangan yang tidak memuat kepentingan-kepentingan parsial yang mengutamakan kepentingan pribadi dan kelompok serta mengabaikan kemaslahatan bersama. Demikian juga budaya hukum akan berjalan baik, jika masyarakat dengan sukarela mengikuti aturan hukum dan tidak menggunakan cara-cara yang justru merusak tatanan hukum dalam menyelesaikan masalahmasalah hukum yang dialaminya.

Pada pengamatan penulis, saat ini Indonesia memiliki persoalan pada ketiga unsur hukum itu sehingga kerberhukuman di Indonesia belum juga menunjukan praktek terbaik model hukum yang berbasis Pancasila sebagai konsepsi ideal. Contoh-contoh yang dapat diajukan untuk mendukung argumen ini telah diuraikan pada bagian fenoma hukum di atas. Pada konteks inilah dibutuhkan generasi yang cerdas berhukum dan disana jugalah peran mahasiswa dalam menciptakan generasi itu.

Prof Tjip dengan mengutip Francis Fukuyama mencontohkan bagaimana kecerdasan masyarakat berpengaruh kepada kecerdasannya berhukum melalui komunitas "slugs" yang terbentuk di Amerika. (Rahardjo, 2007: 42-43). Komunitas slugs ini muncul sebagai respon spontan dari masyarakat terhadap adanya pengaturan yang mewajibkan kendaraan (mobil) pada jam-jam sibuk 
pada rute yang ditentukan wajib mengangkut sedikitnya tiga penumpang sebagai syarat untuk melewati rute itu. Model ini sama dengan model three in one yang diterapkan di Jakarta.

Komunitas slugs ini dengan berjalannya waktu kemudian secara spontan menciptakan separangkat aturannya sendiri atas dasar kesamaan kepentingan yang ada. Pemilik mobil mau tidak mau harus mengangkut penumpang agar bisa melewati rute tersebut sedangkan penumpang juga memerlukan fasilitas mobil untuk melewati rute yang sama. Dalam relasi ini muncul peraturan spontan seperti kewajiban penumpang dan pemilik mobil untuk antri, hak untuk menolak penumpang atau menolak mobil yang tidak dikehendaki, larangan merokok dan membayar, dan pembicaraan yang menghindari topik-topik kontroversial seperti seks, agama dan politik. Dalam kurun waktu 13 tahun hanya terjadi dua kali insiden. Bandingkan dengan pelaksanaan three in one di Jakarta yang justru semrawut, dikomersialkan dan rawan kejahatan.

Fenomena slugs dan komunitas three in one di Jakarta ini menunjukan perbedaan kecerdasan berhukum menghasilkan perbedaan budaya hukum masyarakat dan pengaruhnya terhadap struktur dan substansi hukum. Bahkan dengan pengaturan hukum yang ketat, harmoni tidak juga tercapai. Kecerdasan yang terbangun bukannya kecerdasan untuk menempatkan diri sebagai bagian dari pencapaian tujuan hukum melainkan kecerdasan untuk menghindarkan diri dari hukum dan keteraturan atau kecerdasan mengabaikan dan mencari celah-celah hukum demi kepentingan pribadi dan kelompok.

Mahasiswa memiliki peran signifikan pada pembentukan kecerdasan hukum tersebut dan memposisikan diri sebagai generasi yang cerdas berhukum. Tentu saja mahasiswa tersebut harus terlebih dahulu mencerdaskan keberhukumannya. Peran signifikan ini setidaknya didukung oleh empat elemen, pertama, Mahasiswa merupakan vocal point perubahan (agent of change): sudah berkali-kali mahasiswa membuktikan bahwa seluruh ruang diskursus publik yang ada dapat dipengaruhi oleh mahasiswa melalui berbagai bentuk aktifitas baik akademik dan non akademik. Melalui berbagai aktifitasnya, mahasiswa dapat terjun langsung kepada masyarakat untuk mengadakan perubahan-perubahan pada paradigma dan struktur sosial masyarakat.

Kedua, pembentukan karakter positif melalui mekanisme kaderisasi dan aktiftas keorganisasian: mahasiswa, terutama yang mengikuti aktifitas keorganisiasian sudah sangat terbiasa dengan berbagai model sistem kaderisasi dan aktifitas keorganisasian yang seharusnya dapat membentuk karakter positif mahasiswa yang bersangkutan. Karakter positif inilah yang diharapkan akan 'ditularkan' sebagai teladan oleh mahasiswa kepada masyarakat umum.

Ketiga, pengembangan multi kecerdasan (kecerdasan intelektual, emosional, spritual, linguistik, dll): proses pembelajaran mahasiswa yang sudah spesifik pada konten keilmuan tertentu maupun pada bidang-bidang yang umum untuk membangun kesadaran berbangsa dan bernegara misalnya melalui Mata Kuliah Umum Pendidikan Kewarganegaraan yang diikuti oleh seluruh mahasiswa untuk melengkapi pemahaman kewarganegaaan yang telah dipelajari selama 12 tahun melalui mata pelajaran Pendidikan Pencasila dan Kewarganegaraan (PPKn) di sekolah. Dimiliknya multi kecerdasan ini oleh mahasiswa semestinya memberikan bekal kepada mahasiswa untuk bisa menempatkan diri sebagai bagian integral dari keberhukuman.

Keempat, pembentukan generasi cerdas, pembelajar, kristis, konstruktif dan produktif: proses belajar itu semestinya juga membentuk generasi cerdas yang mampu mengkonstruksikan prilaku dan cara berpikirnya sebagai alternatif solusi bagi berbagai permasalahan-permasalahan yang ada sehingga diharapkan melalui 
proses yang belajar yang diikutinya itu, mahasiswa bukanlah bagian dari masalah dalam konteks kecerdasan hukum ini.

Peran signifikan mahasiswa tersebut secara ringkas dapat disebutkan bahwa, ke depan, mahasiswa semestinya berperan untuk merubah keadaan keberhukuman kita. Alasan mengapa peran ini dapat dilakukan oleh mahasiswa sebagai berikut:

1) Tingkat pendidikan mahasiswa yang lebih tinggi dari pada masyarakat pada umumnya, 2) Sangat dimungkinkan bagi mahasiswa untuk membangun kerangka berpikir berbasis keilmuan, kristis, konstruktif dan memberikan solusi, 3) Dengan ilmunya, kemampuan mahasiswa menelaah informasi lebih matang dan rasional, 4) Diharapkan masih mempertahankan nilai-nilai idealisme, 5) Didukung dengan aktifitas kemahasiswaan yang membuat mahasiswa menjadi lebih sensitif terhadap lingkungan dan situasi, 6) Ruang lingkup interaksi sosial yang lebih luas. 7) Jangkauan informasi yang lebih luas

Secara statistik, keadaan kepemudaan (termasuk di dalamnya mahasiswa) dalam hal pengembangan kecerdasan cukup memprihatikan. Data statistik Pemuda Indonesia tahun 2015 yang diluncurkan oleh Badan Pusat Statistik (BPS) menunjukan bahwa pemuda Indonesia memiliki masalah yang serius dalam hal budaya baca. Hanya 43, 57 persen yang membaca dalam seminggu terakhir. Dari jumlah itu, hanya 27, 32 persen yang membaca buku dan 14,69 persen yang membaca surat kabar atau majalah cetak. Sisanya 31,65 persen menjadi artikel dan berita elektronik sebagai bacaan utama.

Keadaan ini mengkhawatirkan terutama dengan banyaknya hoax, fitnah, dan berita pelintiran di media sosial yang menjadi sumber bacaan pemuda itu. Demikan juga dalam partisipasi mengunjungi perpustakaan, hanya 11,75 persen pemuda yang berkunjung keperpustakaan dalam wakti 3 bulan. Bahkan, untuk Taman Bacaan Masyarakat (TBM), hanya o,63 persen pemuda yang berkunjung kesana. (Lengkapnya data statistik ini dapat dilihat di Badan Pusat Statistik, Statistik Pemuda Indonesia 2015, Badan Pusat Statistik, 2015. Buku ini dapat di unduh di https://www.bps.go.id/index.php/publikas $\mathrm{i} / 4316)$

Rendahnya budaya baca ini menjadi persoalan serius dalam mengambangkan generasi yang cerdas berhukum. Korelasinya adalah, kecerdasan berhukum itu membutuhkan kecerdasan intelektual yang ditopang oleh kecerdasan emosional dan kecerdasan spritual. Jika budaya bacanya rendah, bagaimana kecerdasan itu terbangun dan bagaimana kecerdasan hukum akan tercipta untuk selanjutnya bagaimana mahasiswa akan merubah keadaan?

\section{SIMPULAN}

Menyadari berbagai permasalahan kerberhukuman sebagaimana telah diuraikan di atas, tantangan sesungguhnya bagi mahasiswa adalah bagaimana mahasiswa akan mencerdaskan kerbehukumannya sendiri sebelum akhirnya mahasiswa mencerdaskan keberhukuman masyarakat dan mencerdaskan keberhukuman bangsa. Ini bukan persoalan mudah mengingat minimnya akhir-akhir ini keteladanan dan munculnya berbagai pengaruh yang dapat merusak dinamika berpikir seperti narkoba, pornografi, hoax dan perubahan gaya hidup. Butuh komitmen yang tinggi dari mahasiswa untuk menjadikan diri sebagai komponen ideal membangun kecerdasan hukum. Peran sehari-hari yang sangat mungkin dilakukan oleh mahasiswa dalam mengembangkan kecerdasan berhukum adalah komitmen untuk tidak melakukan plagiasi dalam pengerjaan tugas-tugas perkuliahan. Peran lainnya dalam masyarakat menjadi contoh keteladanan dalam berlalu lintas dan tidak terlibat dalam model-model anarki dalam menyelesaikan permasalahanpermasalahan serta mempelajari konstruksi hukum sebelum memberikan pandangan-pandangannya terkait 
permasalahan-permasalahan hukum. Sekali lagi, jika kita menginginkan generasi yang cerdas berhukum dan dikemudian hari akan memperbaiki keadaan keberhukuman kita, tantangan sesungguhnya bagi mahasiswa adalah bagaimana mahasiswa akan mencerdaskan kerbehukumannya sendiri sebelum akhirnya mahasiswa mencerdaskan keberhukuman masyarakat dan mencerdaskan keberhukuman bangsa.

\section{DAFTAR PUSTAKA}

Apeldorn, A., (2005), Pengantar Ilmu Hukum, Terjemahan, Jakarta: PT. Pradnya Paramita.

Badan Pusat Statistik, (2015), Statistik Pemuda Indonesia 2015, Jakarta: Badan Pusat Statistik.

Dharma, S dan Rosnah Siregar. (2015). Membangun Pengalaman Belajar Kewarganegaraan melalui Model Pembelajaran Project citizen pada Siswa, Jurnal Pendidikan Ilmu-Ilmu Sosial, 7 (1) (2015): 100-106.

Friedmen, L.M., (2001), American Law An Introduction, terjemahan, Jakarta: PT. Tata Nusa.
Nasution, A.R., (2016), Urgensi Pendidikan Kewarganegaraan sebagai Pendidikan Karakter Bangsa Indonesia melalui Demokrasi, HAM dan Masyarakat Madani, Jurnal Pendidikan Ilmu-Ilmu Sosial, 8 (2) (2016): 201-212

Rahardjo, R., (2007), Biarkan Hukum Mengalir Catatan Kritis tentang Pergulatan Manusia dan Hukum, Jakarta: Buku Kompas.

Suharyanto, A., Armansyah M., Taufik W.H., (2016), Aktualisasi dan Filosofi Konsep Kepemimpian Tradisional Bagi Generasi Muda di Bale Marojahan Medan, Jurnal Pendidikan Ilmu-Ilmu Sosial, 8 (2) (2016): 182-189

https://www.bps.go.id/index.php/publikasi/431 6

www.google.com

http://www.dudungnet.com. "Kasus Minah..." Diakses tanggal 8 Juli 2011

http://www.primaironline.com/berita/hukum/ aguswandi-tandjung-charger-hpdivonis-6-bulan-bui Diakses tanggal 8 Juli 2011

http://www.elsam.or.id/images/uploads/amicu s_curiae_prita.pdf. Diakses tanggal 8 Juli 2011 